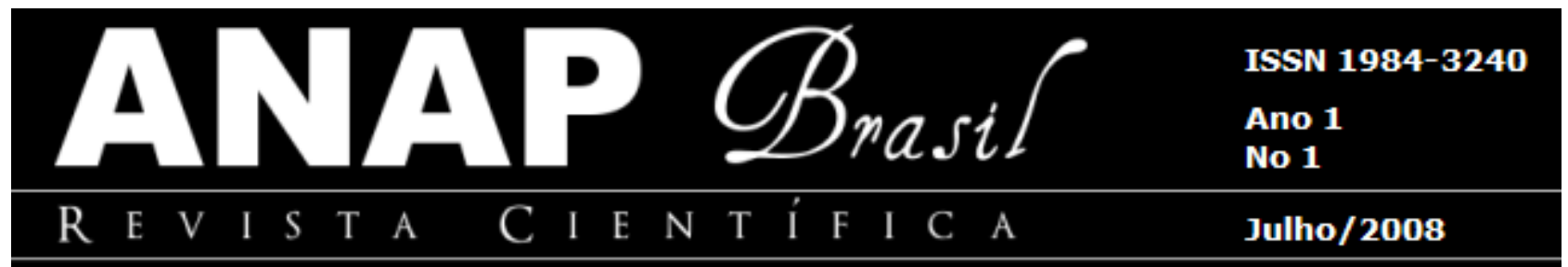

\title{
ANÁLISE INTEGRADA SOB A PERSPECTIVA GEOGRÁFICA DA SUSTENTABILIDADE EM AMBIENTE PECUÁRIO
}

\author{
Maria Betânia Moreira Amador ${ }^{1}$
}

\section{Antônio Carlos de Barros Corrêa ${ }^{2}$}

\section{Aldemir Dantas Barboza ${ }^{3}$}

RESUMO: Este trabalho reflete o esforço acadêmico no âmbito da tese de doutorado em Geografia, no sentido de se procurar realizar um estudo tentando-se integrar a análise morfodinâmica à análise agroecológica, seguindo-se orientações deixadas pelo geógrafo Jean Tricart (1977), na obra "Ecodinâmica". Ao mesmo tempo em que se ressalta o objetivo de, através desse intento, fazer um diagnóstico de caráter dinâmico, pautando-se para isso na escala da propriedade, utiliza-se a metodologia adaptada de Tricart proposta por Corrêa e Azambuja (2005). Tendo-se esse referencial, procedeu-se a pesquisa em campo considerando-se as metodologias de um e outro caso, apresentando-se, ao longo da análise, cartogramas representativos dos níveis categóricos estrutura superficial da paisagem, uso do solo, vegetação e processos superficiais da paisagem, os quais contribuem para o rebatimento no mapa morfodinâmico da parcela estudada nessa propriedade, construído em Corel 12 a partir de croqui trabalhado em campo durante fase de coleta de dados. Com base nas entrevistas e questionários aplicados, tabulou-se os dados obtidos à luz dos princípios agroecológicos, elaborando-se biogramas que fornecem uma idéia do grau de sustentabilidade em cada propriedade, o que vem complementar e endossar resultados conseguidos na análise morfodinâmica. Nesse sentido, mostra-se o trabalho realizado na propriedade Serra do Tará, cuja área analisada localiza-se na unidade geoambiental "Superfícies Dissecadas" no município de PedraPE. Acredita-se ter contribuído, de alguma forma, para a apreensão da sustentabilidade e sua compreensão no espaço considerado.

\footnotetext{
${ }^{1}$ Doutoranda em Geografia, UFPE; Docente, FACETEG/UPE betaniaamador@yahoo.com.br

${ }^{2}$ Pós-Doutor em Geografia, Professor e Pesquisador, UFPE. dbiase@hotmail.com

${ }^{3}$ Doutora em Geografia, Professora e Pesquisadora, UFPE. aldemirdantas@bol.com.br
} 


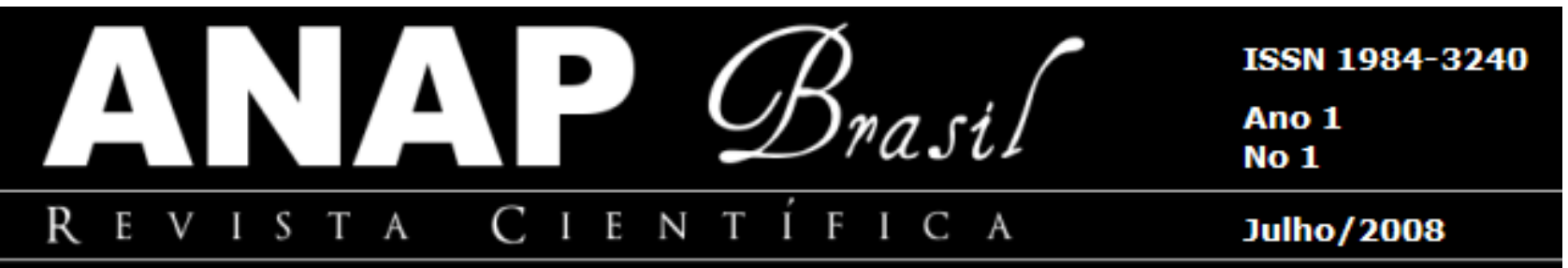

Palavras-chave: Ecodinâmica. Sustentabilidade. Agroecologia.

\section{INTRODUÇÃO}

Esta propriedade está situada na unidade geoambiental Superfícies Dissecadas (Figura 1.1), localizada na Unidade de Paisagem Pediplano Central do Planalto da Borborema, apresentando superfícies com diversos graus de dissecação, relevo ondulado e ocorrência generalizada de solos Podzólicos, às vezes associados com Solos Litólicos (EMBRAPA, 2001).

Parcelas Analisadas Por Unidades Geoambientais Municipio de Pedra- PE

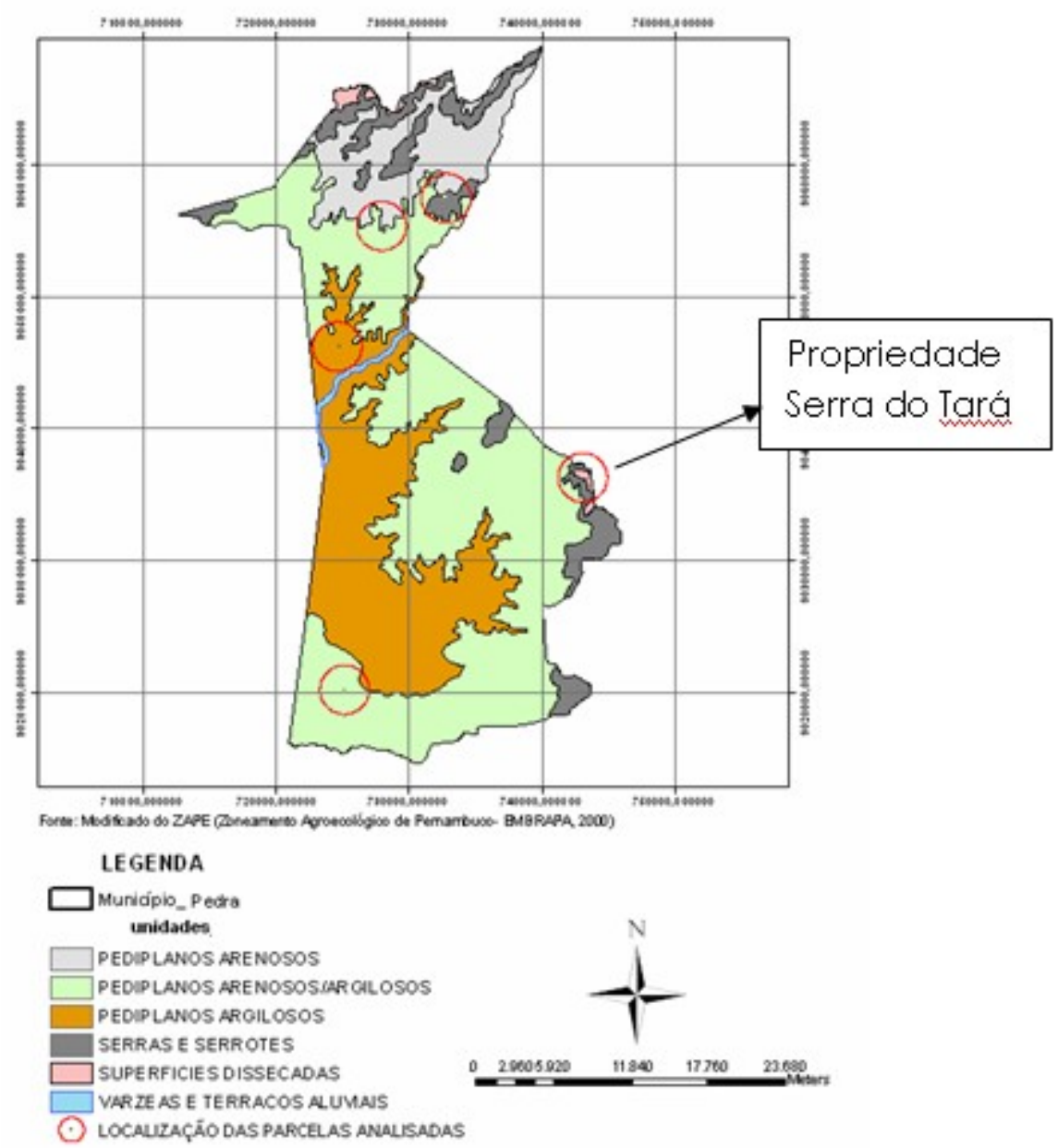




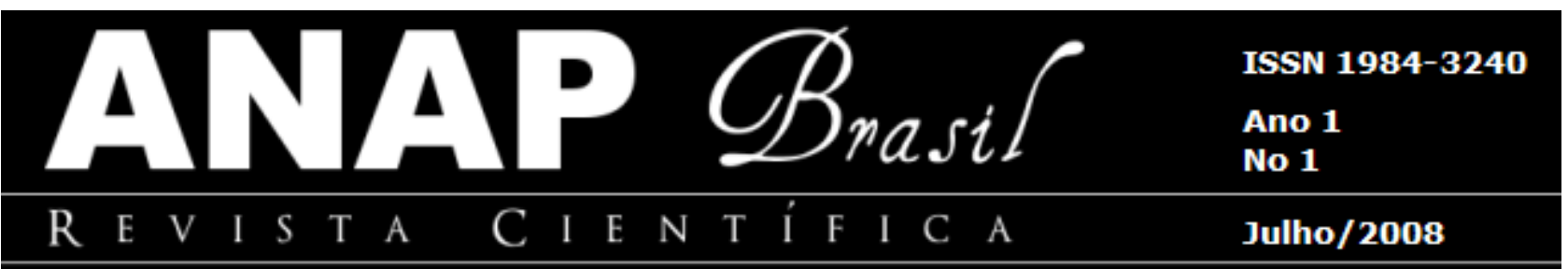

Figura 1.1 - Localização da Propriedade Serra do Tará (Pedra/PE)

Fonte: Pesquisa de campo, 2007

As cotas altimétricas dessa propriedade variam em torno de $729 \mathrm{~m}$, correspondendo a um terreno declivoso, porém não abrupto. Considerando-se a criação animal como o gado bovino, seja para corte ou leite, ter - se uma área de pasto em declive já demanda esforço desprendido e perdido no caminhar pelo pasto e água. Acrescente-se a isso, o fato da área apresentar muitos lajedos à mostra e estar contida numa área de vegetação, ainda, natural embora degradada.

Esta propriedade tem a peculiaridade de ser tocada por um morador antigo e, praticamente a produção lá realizada é de responsabilidade dessa pessoa. Segundo um herdeiro proprietário, essa forma de proceder está em vigor desde o ano de 2002. Porém, seu pai, o proprietário de fato, enquanto vivo manteve pecuária com gado da terra desde a aquisição das terras em 1963 até o ano assinalado acima, tendo em torno de 1963, plantado algarobeiras em plena campanha de expansão da mesma no Nordeste brasileiro, mas sem nenhuma estrutura técnica que lhe desse respaldo.

$\mathrm{Na}$ época do trabalho de campo em 2007, o morador declarou possuir 18 cabeças de gado, das quais 11 estavam produzindo leite. Somem-se algumas cabeças de ovelhas de raça em fase de experiência. No entanto, o forte da produção era/é a produção de leite de gado bovino que no momento da pesquisa estava em torno de 15 litros por vaca dia. Pode-se dizer que este é um bom quantitativo em função da precariedade tecnológica e de estrutura física apresentada pela propriedade, assim percebe-se claramente que o ambiente natural associado à experiência de uma vida faz com que se tenha uma produtividade aparentemente suficiente para a manutenção das pessoas envolvidas e a continuação da atividade.

É importante salientar que o referido morador está na faixa etária dos sessenta anos, sem nenhuma escolaridade e que acompanhou o falecido proprietário desde o início, ou seja, desde a década de 1960 e que possui relativa autonomia para decidir sobre onde, o que e como produzir.

\section{ESTRUTURA SUPERFICIAL DA PAISAGEM}




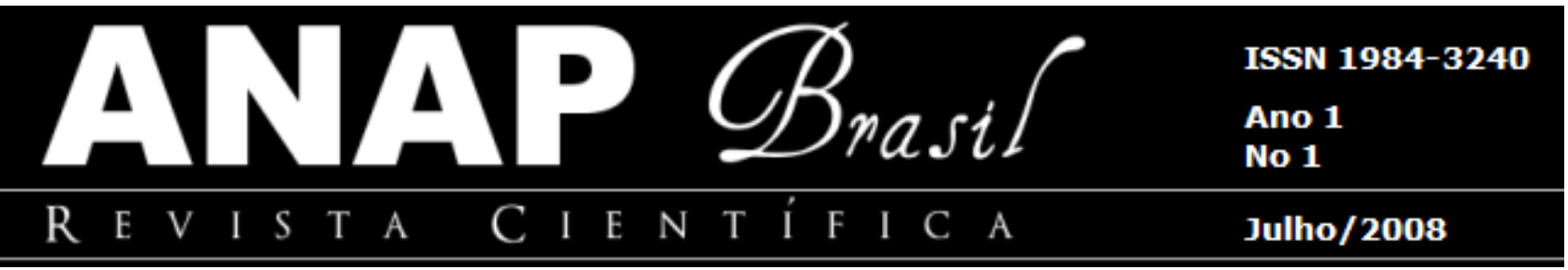

Tomando-se como referência a Carta de Reconhecimento de Baixa e Média Intensidade de Solos, produzida pela Empresa de Pesquisa Agropecuária - Pernambuco (EMBRAPA, 1999), folha Venturosa SC 24 - X - B - V., observou-se que o Sítio Serra do Tará apresenta uma associação de Solos Litólicos Eutróficos "A" fragipã e moderado textura média com cascalho a cascalhenta. Caatinga hiper xerófila, relevo suave ondulado e ondulado. Substrato gnaisse granito, xisto, migmatito e granodiorito mais afloramento de rocha. Os Solos Litólicos se caracterizam:

Por tratar-se de solos tipicamente rasos, isto é, com menos de 0,50 $\mathrm{m}$ de profundidade até o substrato rochoso, sendo pouco desenvolvidos, com sequência de horizontes $A-C$ ou $A-R$. Ocupam posições de relevo que variam de plano a escarpado, e apresentam muita variação quanto à fertilidade natural (CAVALCANTI, 1998, p.20).

As áreas de ocorrência deste solo em Pernambuco, segundo o mesmo documento, são o Agreste e o Sertão prioritariamente. E, em termos de potencialidades e limitações:

Suas maiores limitações são a pequena profundidade efetiva, pedregosidade, topografia movimentada e presença de afloramentos rochosos. Os solos menos pedregosos, com horizonte A mais espesso e com alta fertilidade natural, são usados em sistemas pouco intensivos com algodão, milho, feijão e palma forrageira (lbid, p.20).

Constata-se, no entanto, que a parcela da propriedade analisada evidencia claramente as características próprias de um Solo Litólico, através das manchas mais claras apresentadas no Cartograma correspondente ao Nível Categórico Estrutura Superficial da Paisagem (Figura 2.1).

A área estudada expõe certa rusticidade tendo-se em vista a estrutura do solo que, como se pode apreciar na Figura 2.2, denota a presença de pedregosidade formada a partir da ruptura das estruturas foliadas da rocha matriz e, também, uma espessura de capa de solo muito rasa, com fragmentos rochosos de diversas dimensões predominando a estrutura em blocos, tomando-se por base o documento do Departamento de Agricultura de los Estados Unidos de Norteamérica - USDA (2000, p. 24). 

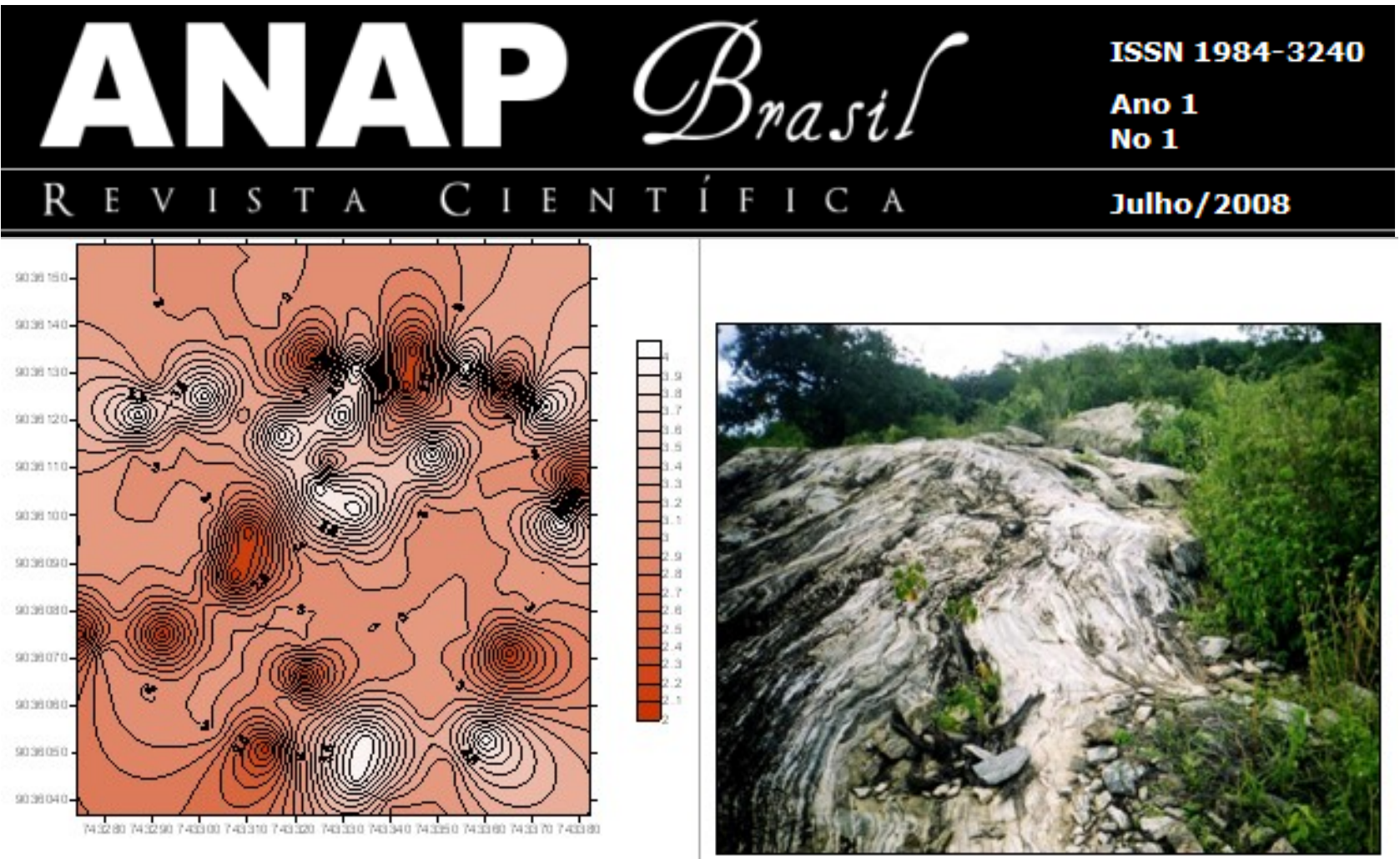

Figura 2.1 - Cartograma de Isovalores de Estabilidade Ambiental do Nivel Categórico

Estrutura Superficial da Paisagem (Serra do Tará)

Fonte: Pesquisa de Campo, abr. 2007
Figura 2.2 - Laje do à mostra evidenciando fragmentos de aspecto foliar (Serra do Tará)

Fonte: Pesquisa de Campo, abr. 2007 .

Foto de Maria Betânia Amador

Dando-se prosseguimento à investigação referente a este nível categórico, tomando-se como ponto de análise a percepção de atividade microbiológica do solo, foi possível verificar a aparente exigüidade dessa atividade pela não observação de vermes, lombrigas do solo, ou outro animal de fauna microbiana que pudesse ser detectado visualmente. Porém, em termos de artrópodes, percebeu-se várias espécies de formigas, mas não foram avistadas panelas.

Quanto à análise do $\mathrm{pH}$ da parcela de estudo da Propriedade Serra do Tará, obteve-se um valor médio de 6,85, próximo da neutralidade. No entanto, procurando-se especificar melhor os valores de $\mathrm{pH}$ obtidos em pontos diversos da parcela descreve-se a seguir a associação feita com a literatura pertinente.

Duas das amostras analisadas pelo Laboratório de Fertilidade do Solo da Universidade Federal Rural de Pernambuco - UFRPE mostraram resultados de 6,5 e 6,3, configurando um indicativo de solo ácido. Segundo o Instituto de Potassa \& Fosfato POTAFOS (1998, p.23), esses valores enquadram-se na faixa de acidez moderada, o que de certa forma não é considerado um problema, tendo por base informações contidas em documento da USAID (2000, p. 60), o qual especifica que para o intervalo de 6,0 a 7,0, e 


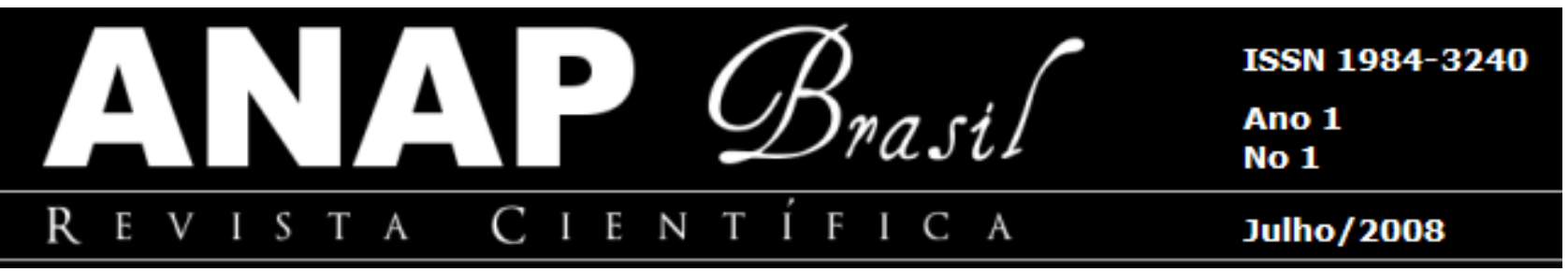

aqui pode ser encaixado o resultado da terceira amostra que foi igual a 7,0, tem-se boa disponibilidade de nutrientes como nitrogênio, fósforo e potássio, bons níveis de alumínio, ferro e magnésio, relativa atividade bacteriana e presença de fungos benéficos que decompõem a matéria orgânica.

Por outro lado, o valor de uma quarta amostra igual a 7,6, denota uma alcalinidade média (POTAFOS, 1998, p.23), podendo ser caracterizado como solo cálcico.

Com relação à matéria orgânica (M.O.), o resultado da análise de solo para essa área de um hectare estudada indicou um valor médio de 3,97\% e que, segundo o documento da Agencia para El Desarrolo Internacional de los Estados Unidos - USAID (2000, p. 127), está muito próximo de 4. Um percentual de matéria orgânica entre 4 e $5 \%$ é considerado normal.

Porém, se for avaliado em micro escala, pode-se perceber que um dos lados da parcela evidenciou um percentual baixo de matéria orgânica, ou seja, 2,46 \%, correspondendo à célula atravessada em parte pela estrada local, por linha de transmissão e presença de várias manchas de solo nu. Salienta-se que esta célula está ao Sul do Cartograma correspondente ao Nível Categórico Estrutura Superficial da Paisagem, mais ou menos na parte central do alinhamento Leste-Oeste coincidindo, também, com a coloração mais clara do Cartograma (Figura 2.1) e conseqüentemente, de maior instabilidade.

Quanto ao teor de Fósforo (P), a parcela de estudo dessa Propriedade evidenciou o valor médio de $53,566 \mathrm{mg} / \mathrm{dm}^{3}$. Neste caso leva-se em consideração que quando se obtém um valor acima de 40 ppm considera-se uma disponibilidade de Fósforo alta, sendo este um elemento importante no contexto da fertilização do solo. $O$ fato de se ter um percentual de Fósforo tão significativo deve-se, provavelmente, às condições físicas apresentadas pela área em apreço. Esta se encontra sobre relevo acidentado, com evidentes indícios de processos superficiais nos quais ocorre o desgaste do relevo expondo rochas que, naturalmente liberam fosfato.

Diferente do carbono e do nitrogênio, cujos principais reservatórios ficam na atmosfera, o reservatório principal do fósforo está no solo. Ele ocorre naturalmente no ambiente, na forma de fosfato. Os fosfatos podem estar na solução do solo como íons de fosfato inorgânico (...) ou como parte de compostos orgânicos dissolvidos. Porém, a fonte principal de fosfato é a intemperização do material de origem; portanto, o aporte e a ciclagem do fósforo nos agroecossistemas ficam 


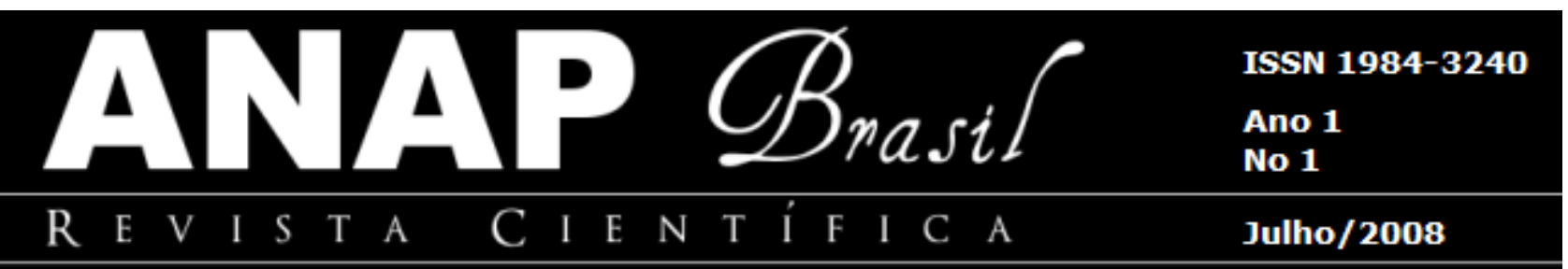

limitados pela taxa relativamente lenta deste processo geológico (GLIESSMAN, 2005, p. 225).

A análise de solo na parcela de estudo da Propriedade Serra do Tará, evidenciou um valor médio de Potássio (K) de 261,97 ppm que, segundo o documento USAID (2000, p. 127), é considerado normal pois se encontra no intervalo de $250-350$ ppm. Apesar de o Potássio ser considerado o mais móvel dos nutrientes no sistema solo-planta-atmosfera, sua absorção pela planta não se dá tão facilmente, pois dependem de uma série de fatores como a intercepção radicular, o fluxo de massa e a difusão. No entanto, medições realizadas nos Estados Unidos e no Brasil mostram que "a participação maior para o contato do K com a raiz é a difusão, pois este nutriente caminha distâncias curtas dentro da fase aquosa estacionária" (MALAVOLTA, 2004, p.3). Por outro lado, deve-se lembrar que a área de estudo, como um todo, é sujeita ao fenômeno seca, o qual pode interferir nesse processo de difusão pela diminuição da solução aquosa existente no solo.

\section{USO DO SOLO}

Em continuidade, apresenta-se algumas considerações relativas ao nível categórico uso do solo, o qual é predominantemente pastagem. No Cartograma correspondente (Figura 3.1), é possível se observar várias manchas de instabilidade ambiental, porém provenientes de outros fatores como áreas de pasto desgastadas e impróprias pela presença significativa de lajedos e muito solo descoberto e/ou vegetação muito esparsa.

A área clara no setor Sudoeste desse Cartograma de Uso do Solo corresponde à finalização do trajeto de uma estrada local (Figura 3.2), que dá acesso à moradia principal da propriedade. Nessa posição a predominância de solo nu é marcante. Tem-se nesse local o solo ocupado por residência, eletrificação, caixa d'água nas proximidades e pequenas trilhas de adentramento à área analisada. 

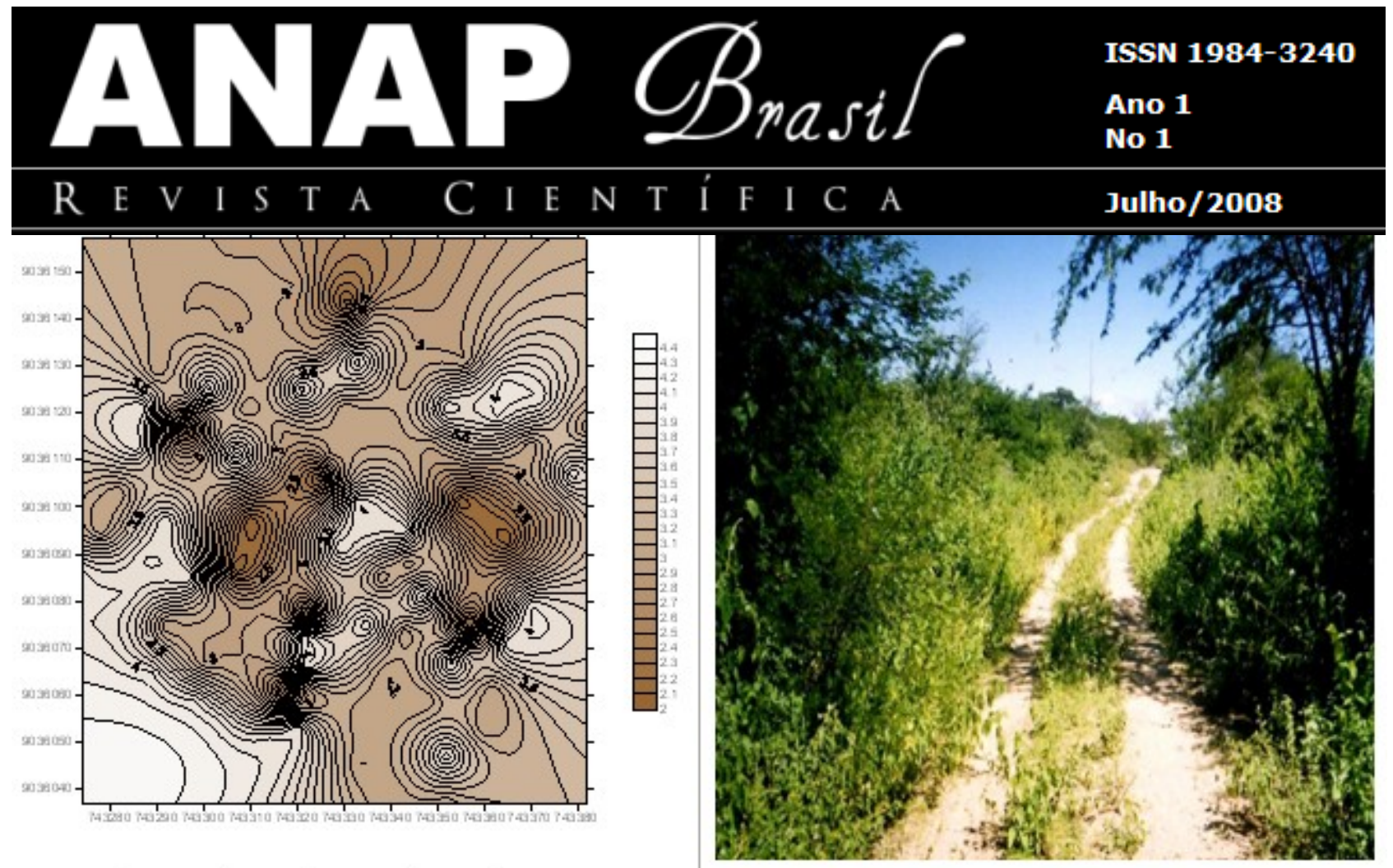

Figura 3.1 - Cartograma de Isoyalores de

Estabilidade Ambiental do Nível

Categórico Uso do Solo (Serra do Tará)

Fonte: Pesquisa de campo, 2007 .

Figura 3.2 - Vista da estrada local (S. Tará)

Pesquisa de Campo, abr. 2007

Foto de M. Amador

Também nas proximidades da casa principal, encontrou-se início de voçorocas caracterizadas por valas no sopé da descida do terreno, ou seja, o criatório bovino não contribuiu para essas fendas e sim o escoamento superficial das águas, sem um direcionamento correto do fluxo.

Outro dado que pode ser referenciado nesse espaço de discussão diz respeito à cor do solo. É possível perceber-se pela Figura 3.2, que o solo desnudo tem uma coloração esbranquiçada:

Indicando a presença de quartzo, carbonatos ou gesso (...). Além disso, pode ter influência na interação com outros fatores do ambiente. Por exemplo, em alguns sistemas tropicais de produção agrícola pode ser vantajoso ter um solo arenoso, de coloração clara na superfície, a fim de refletir os raios solares e mantê-los mais frescos (GLIESSEMAN, 2005, p. 221).

No campo, encontrou-se certa concentração de material quartzoso realmente e, se for aplicado essa noção ao gado talvez seja para ele também um ponto de bem-estar considerando-se a insolação característica do semi-árido. Como se trata de uma área elevada e com vegetação relativamente densa, espera-se que o calor seja atenuado para 


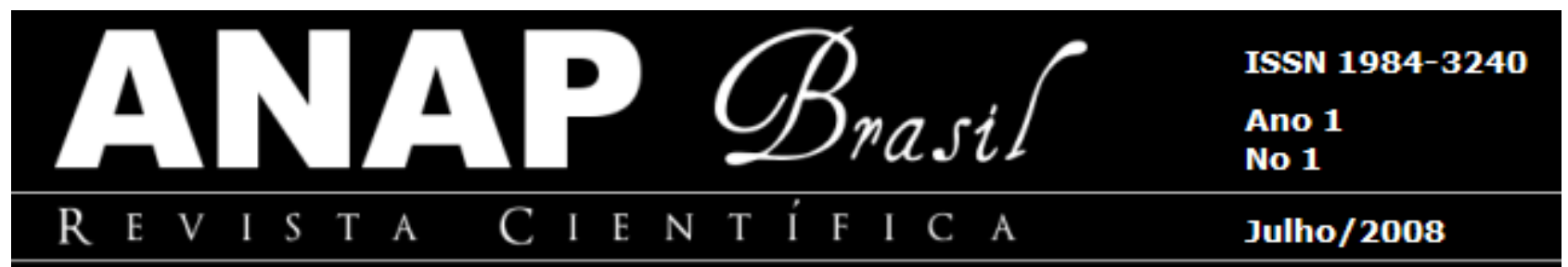

os animais, salientando-se que o "gado da terra" dessa propriedade possui coloração escura em sua maioria.

\section{VEGETAÇÃO}

Na parcela analisada da Propriedade Serra do Tará, o pasto e a caatinga são praticamente uma coisa só, apesar de se sentir que a vegetação não corresponde à sua verdadeira essência devido ao fato de em anos anteriores ter sido exaurida de alguma forma e, na entrevista feita com um dos herdeiros ficou constatado que na década de 1960, no auge da algaroba, foram feitos extensos plantios dessa leguminosa, no entanto, o que se viu por ocasião da pesquisa em relação à sua presença foram, apenas, alguns remanescentes.

Pelo Cartograma de Vegetação (Figura 4.1), verifica-se que predomina o nível 3 que, na escala de isovalores pré-estabelecida pelo método utilizado está mais próximo da instabilidade do que da estabilidade.

Embora em campo tenha-se observado o aspecto verde homogêneo da pastagem, logo ideal para o gado, em termos de estabilidade erosiva da parcela as constatações apontam noutro sentido. O que se viu foi uma grande diversidade de plantas, principalmente referente às plantas de pasto, distribuídas de forma muito aleatória e com presença de algumas plantas consideradas tóxicas para o gado. Ademais, as manchas bem claras que aparecem no Cartograma de Vegetação (Figura 4.1), são correspondentes às principais áreas de lajedos, logo sem vegetação, e também manchas de solo desnudo. 


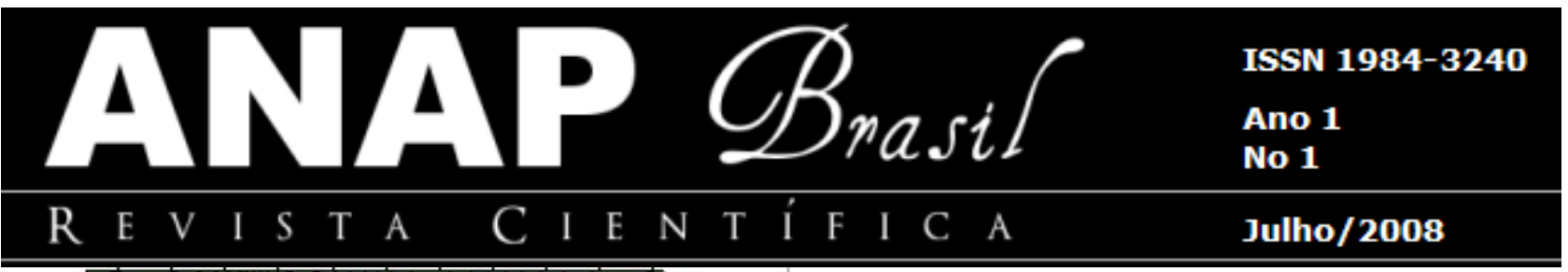

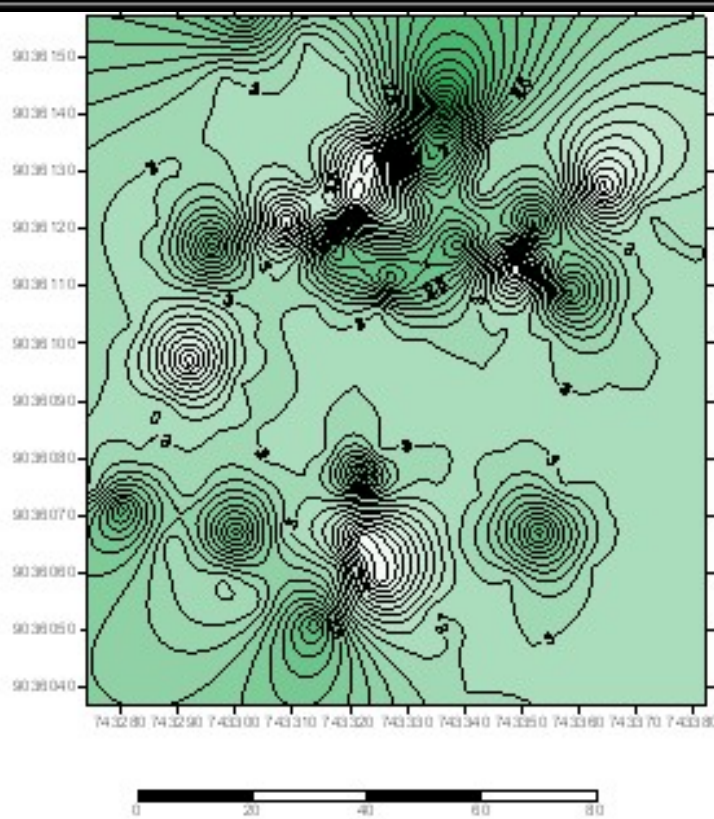

Figura 4.1 - Cartograma de Isoxalores de Estabilidade Ambiental do Nível Categórico Vegetaçã̃o

Fonte: Pesauisa de camno. 2007

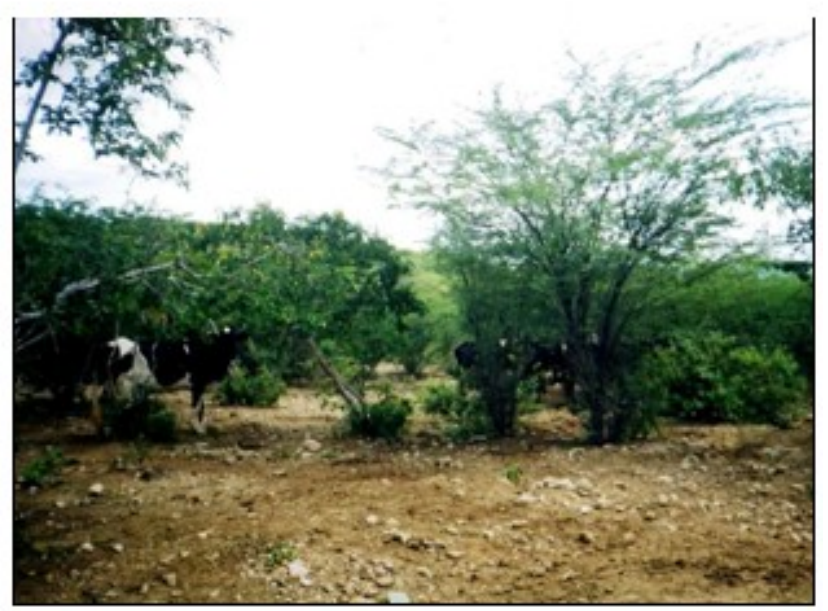

Figura 4.2 - Algarobeiras no pasto Fonte: Pesquisa de Campo, abr. 2007 Foto de Maria Betânia Amador

Por outro lado, a concentração de maior estabilidade, equivalendo a 2 e 2,5, corresponde às áreas com pasto arbóreo-arbustivo e presença de algum pasto herbáceo, em princípio de melhor característica fito-fisionômica. A seguir expõe-se uma breve descrição de algumas espécies de maior importância no agroecossistema pecuário e que são peculiares a esta propriedade, com base na literatura consultada sobre o assunto.

De acordo com Mendes (1989), a algarobeira (Prosopis juliflora (SW) DC), é uma espécie exótica muito apreciada pelos animais devido às suas vagens (algarobas), adocicadas e ricas em proteína e provedora de excelente sombra para os animais. Em campo, constatou-se que, embora as árvores dessa espécie tenham sido quase que erradicadas da propriedade Serra do Tará, ainda assim foi possível observar-se sua presença em meio ao pasto (Figura 4.3) e alguns animais próximos a elas.

A Jurema preta (Mimosa hostilis Benth), é uma leguminosa arbórea de pequeno porte, chega a alcançar até $5 \mathrm{~m}$ de altura por $0,20 \mathrm{~cm}$ de diâmetro; casca escura com acúleos. Sua madeira é muito dura, castanho-escura, geralmente utilizada para carvão em fundições, dado seu alto poder calorífico. Da casca de suas raízes, faziam certas tribos de índios - Carajás e outras - bebidas estupefacientes e alucinatórias, com características semelhantes à dos ampliadores de consciência (ESTEVÃO; LIMA apud 


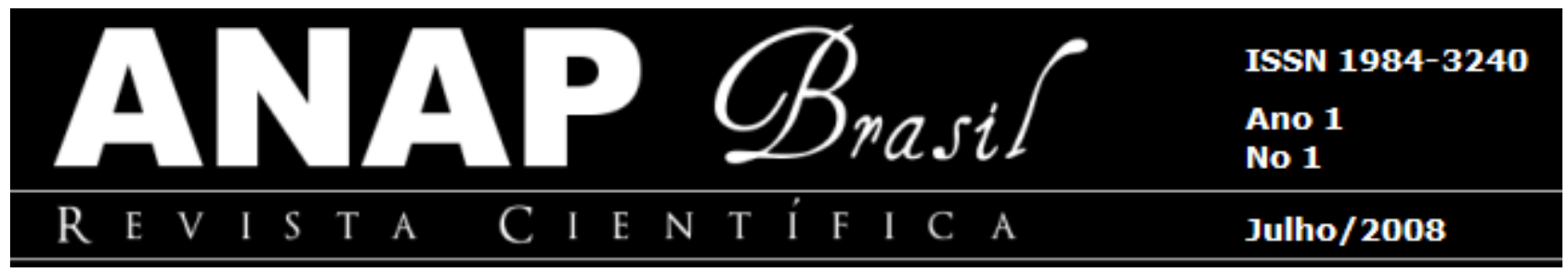

VASCONCELOS SOBRINHO, 2005, p.76). Seu aproveitamento pelos bovinos, em especial vacas gestantes, não é aconselhável pelo fato de ser comprovado cientificamente que os animais nascem com malformações (RIET-CORREA ET AL., 2006 apud SILVA, 2006).

A Umburana ou Imburana, dependendo de como é falada pelo morador, refere-se às espécies descritas em Vasconcelos Sobrinho (2005, p. 77), como sendo Imburana de Cheiro (Torresea cearensis Fr. All.), e Imburana de Cambão (Bursera leptophloeos Mart.), a primeira chegando a 10 metros e a segunda tendo características de pequeno porte. É uma leguminosa possuidora de madeira de pouca resistência, de cor castanha clara, porém fácil de trabalhar e muito procurada para revestimento de móveis, por exalar cheiro que afugenta os insetos. Sua importância econômica provém da essência odorífica de que são ricas as sementes, semelhante ao cumaru verdadeiro.

Cita-se, também, com exemplo da vegetação encontrada na parcela analisada: Mela-bode (Malvaceae), Velame (Euphorbiaceae), Camará (Verbenaceae), Malva (Malvaceae), Vassourinha (Scrophulariaceae), Xique- xique (Cactaceae), Facheiro (Cactaceae), Mandacarú (Cactaceae), Coroa-de-frade (Cactaceae), Moleque duro (Ehretiacea), Macambira (Bromeliácea), Alecrim (Lamiaceae), Malícia (Leguminoseae), Capim buffel (Gramineae), Capim mimoso (Gramineae), Urtiga (Euphorbiaceae).

Logo, apesar da diversidade em termos de espécies vegetais, percebe-se que estas não atendem plenamente às necessidades nutricionais dos animais. Os recursos são suficientes, apenas, para mantê-los em atividade, tendo a sensação que estão se alimentando e que não chegam a morrer de fome. Geralmente, sua dieta é complementada com palma, a qual é plantada em outro local da propriedade e não na parcela analisada (Figura 4.3). Os animais quando são trazidos para se alimentarem no côcho (Figura 4.4), recebem uma dose regular de palma e rações em pequenas proporções, o suficiente para manter a produção diária de leite. 

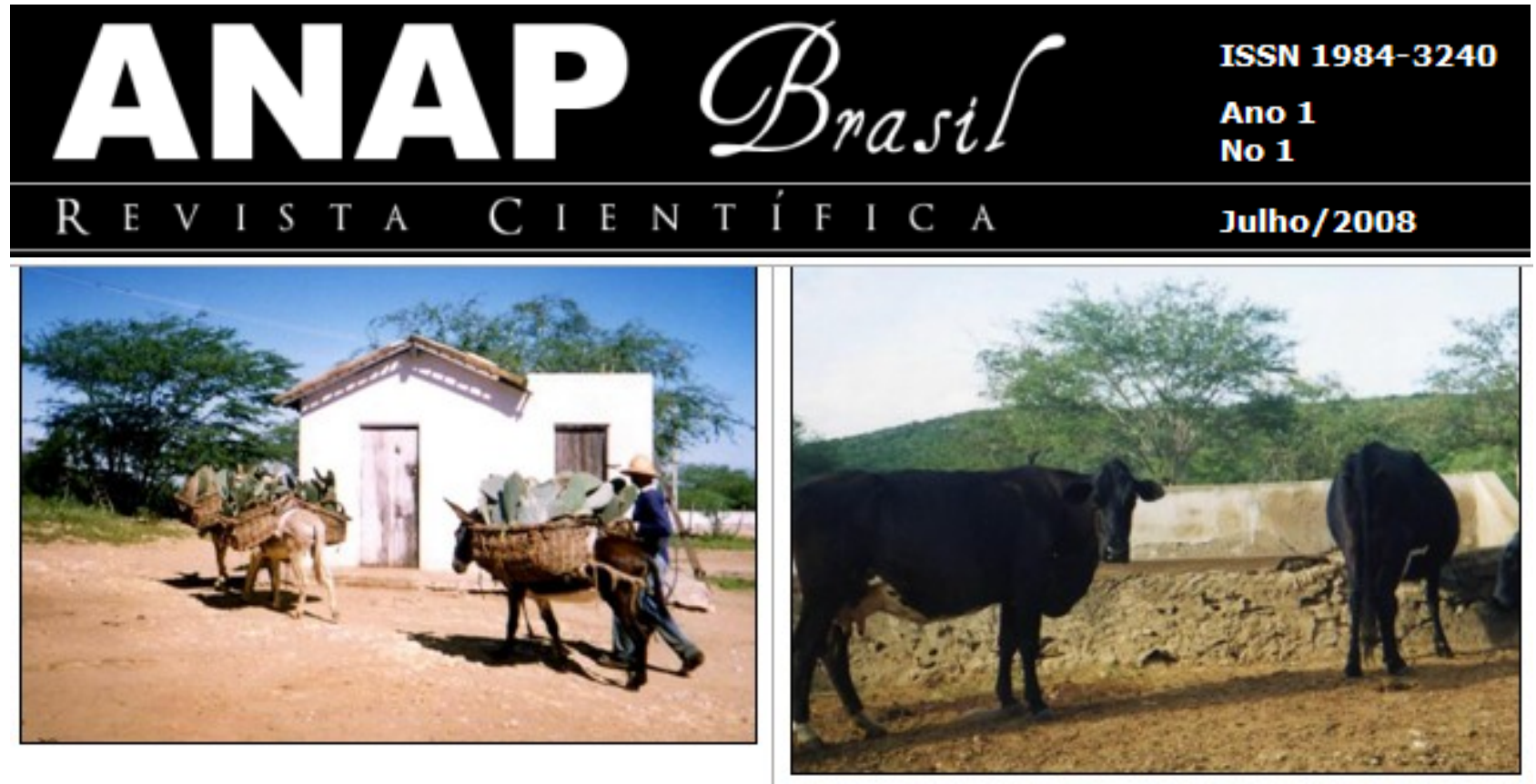

Figura 4.3 - Carregamento de palma de uma área

Figura 4.4-Animais no côcho (S. Tará)

da propriedade para outra

Fonte: Pesquisa de Campo, abr. 200Z

Fonte: Pesquisa de Campo, abr. 200Z

Foto de Maria Betânia Amador

\section{PROCESSOS SUPERFICIAIS DA PAISAGEM}

Observando-se o Cartograma (Figura 5.1), pode-se ver altos níveis de instabilidade correspondendo em campo às áreas mais impactadas tanto pelo corte da estrada quanto pela passagem da eletrificação, presença de vários afloramentos de rocha, lajedos e manchas desolo desnudo, agravando-se com o declive acentuado do terreno, o que proporciona a predominância do tipo de erosão linear (Figura 5.2). 


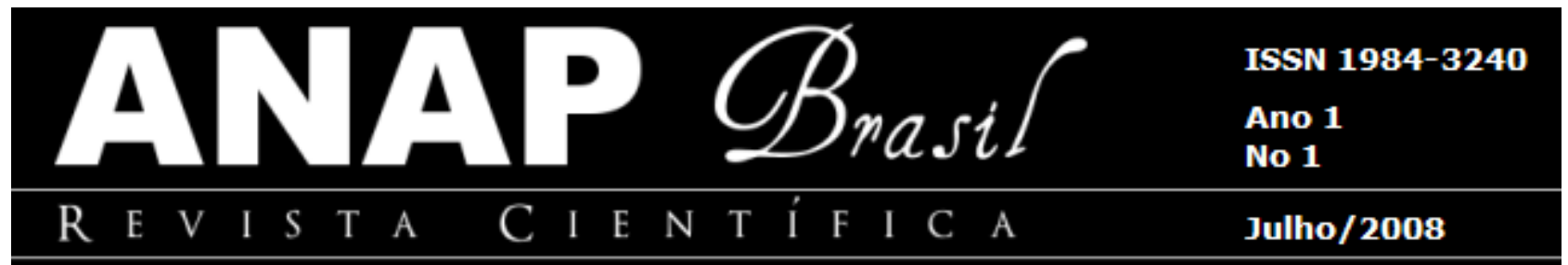

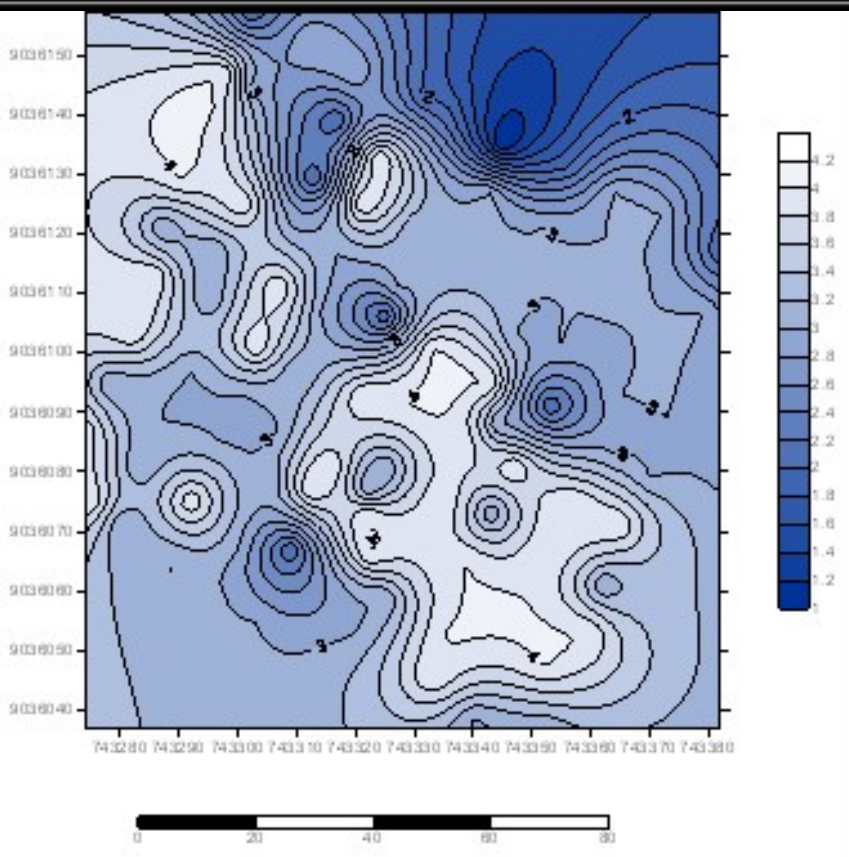

Figura 5.1 - Cartograma de Isovalores de Estabilidade Ambiental do Nivel Categórico Processos Superficiais da Paisagem (Serra do Tará)

Fonte: Pesquisa de Campo, abr. 2007

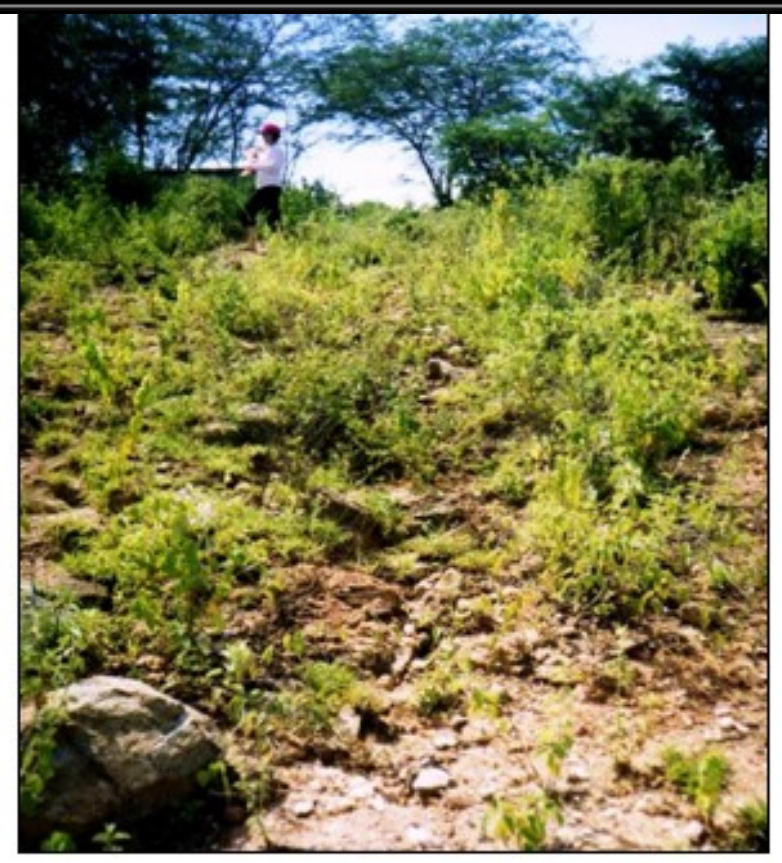

Figura 5.2 - Trecho em declive acentuado com marcas de erosẫo linear

Fonte: Pesquisa de Campo, abr. 2007 Foto de Maria Betânia Amador

\section{ANÁLISE MORFODINÂMICA}

Finaliza-se esta etapa da análise ecodinâmica da parcela de estudo da Propriedade Serra do Tará, levantando os principais pontos críticos observados e revelados pelos cartogramas dos níveis categóricos já detalhadamente explorados anteriormente, os quais podem ser confrontados com o Mapa Morfodinâmico (Figura 6.1) a seguir. 

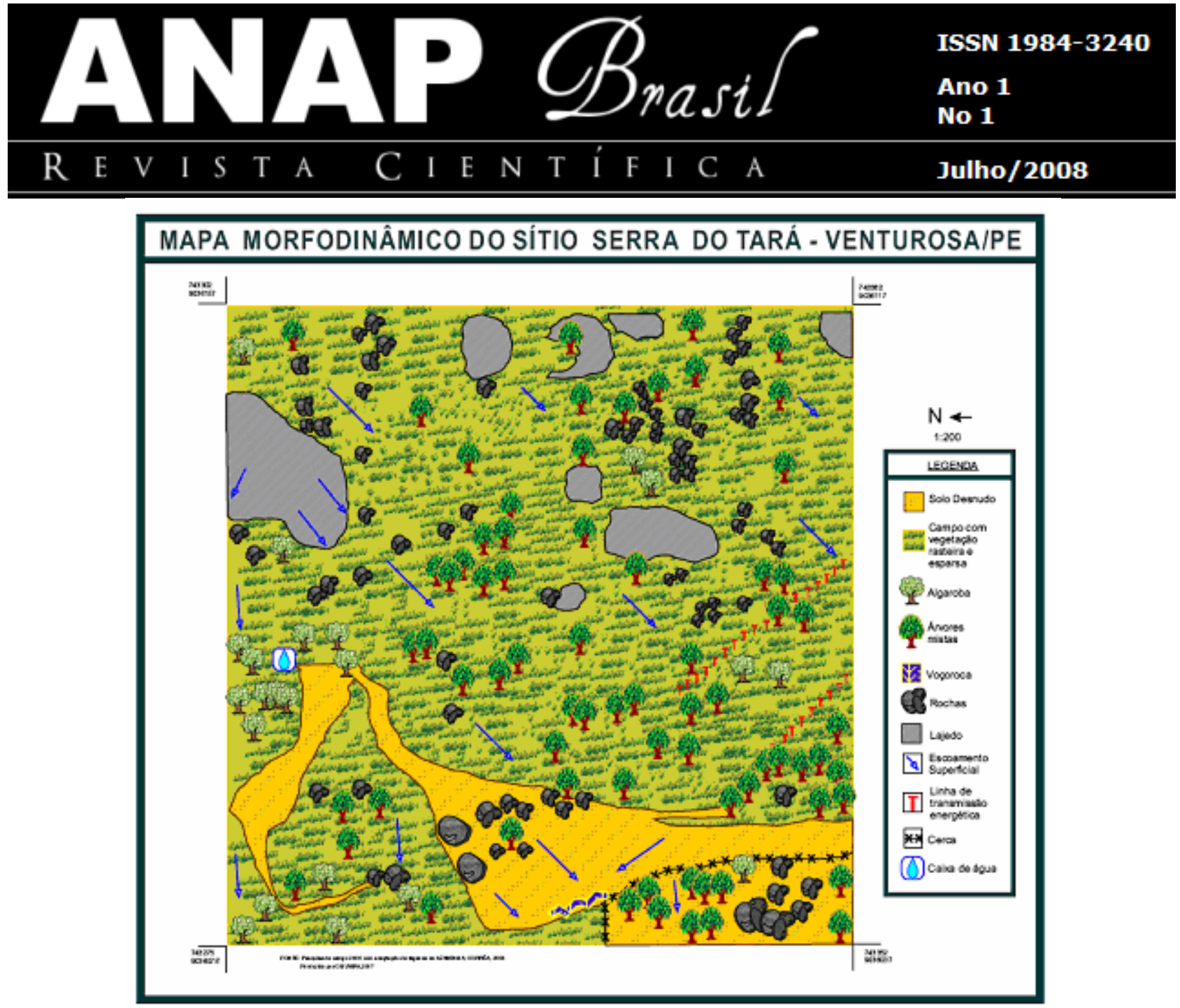

Figura 6.1 - Mapa Morfodinâmico do Sítio Serra do Tará - Pedra/PE Fonte: Pesquisa de Campo, abr. 2007 Desenho: Paulo Oliveira

Primeiramente, trata-se de uma propriedade que está assentada em terreno com muita declividade e com poucas áreas em patamares planos. Pode-se observar que as áreas mais altas da parcela estudada encontram-se ao Norte, desse Mapa Morfodinâmico, estando a estrada local de acesso ao sopé da inclinação, o que de certa forma contribui para processos erosivos.

Observando-se o Cartograma da Estrutura Superficial da Paisagem (Figura 2.1), verifica-se a grande quantidade de lajedos e rochas existentes na parcela analisada, caracterizados pelas manchas de tonalidade mais claras sobre o cartograma. Esse solo, juntamente com a declividade acentuada não são fatores favoráveis ao desenvolvimento de uma área de pasto para bovinos.

Em relação ao Cartograma Uso do Solo (Figura 3.1), está claro o aproveitamento principal como área de pastagem, porém ao natural e sem nenhum recurso tecnológico associado, apesar dos indícios de capim buffel e outros, mas que são resquícios de uma 


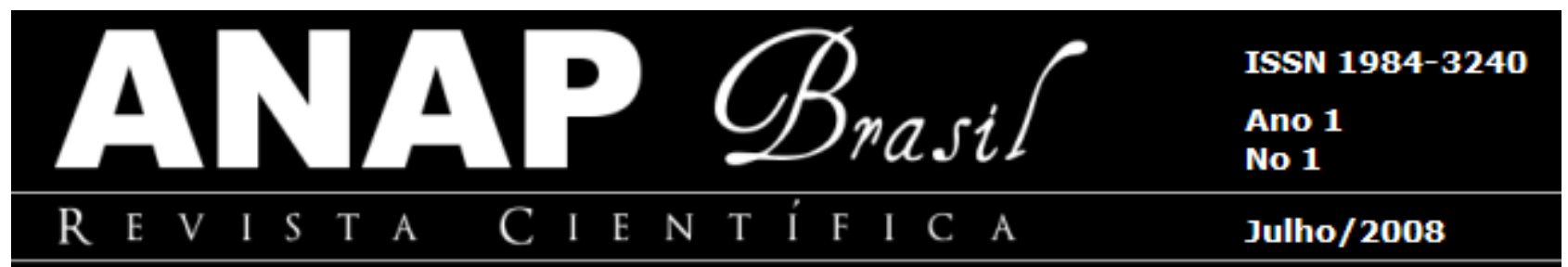

época passada, cujas marcas na paisagem denotam o esforço empreendido na busca de uma pecuária realizada de forma mais apropriada. Também fica evidente a presença de cercas perceptíveis no setor sudeste da parcela, que indica haver algum tipo de manejo, pois não se constitui em separação territorial. Bem como, é possível observar o cruzamento, praticamente na mesma área por onde passa a cerca, da rede elétrica, além da extensa área de solo desnudo vistas, também, predominantemente ao sul da parcela.

Por sua vez, a cobertura vegetal corresponde mais a uma caatinga arbustivoarbórea com indícios de ter havido tentativas de incorporá-la ao restante da propriedade pelo plantio de capim e de algaroba.

No entanto, o que se observa no Cartograma de Vegetação (Figura 4.1), é o predomínio do índice próximo da instabilidade, isso porque a maioria das plantas encontradas não é adequada à nutrição animal tendo-se, inclusive, encontrado certa concentração da planta camará, considerada um perigo aos animais pela sua alta toxidez. Some-se a esses fatores a agressividade de grande parte dessas plantas como o mandacaru e outras espécies presentes em número significativo na área estudada.

No que se refere à análise referente ao Cartograma dos Processos Superficiais da Paisagem (Figura 5.1), tem-se uma tendência para a sustentabilidade no quadrante superior nordeste, da parcela, local onde o terreno mostra pouca inclinação, menos lajedos e não se percebeu ravinamentos ou voçorocas. Ao passo que nas áreas de manchas claras sobre esse cartograma há um escalonamento de índices que apontam para a situação de instabilidade, principalmente devido ao escoamento de forma linear do fluxo d'água.

\section{ANÁLISE AGROECOLÓGICA}

Em continuidade, no conjunto da análise ecodinâmica, pinça-se o estudo agroecológico procurando-se integrar os elementos de uma forma que se possa ter uma visão sistêmica da propriedade e sua atividade. 


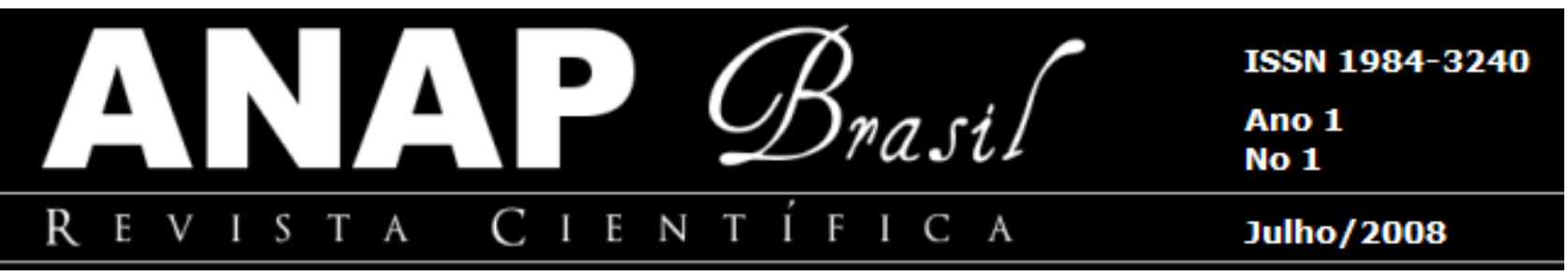

Em seqüência, apresenta-se o Biograma Síntese de Sustentabilidade da Propriedade Serra do Tará apresentado abaixo (Figura 7.1), verifica-se que este sítio encontra-se no limiar da sustentabilidade / insustentabilidade, uma vez que a maioria das dimensões evidenciam valores médios abaixo ou iguais a 5 , este estabelecido com base em Altieri; Nicholls (2007), apenas a dimensão técnica expressa valor acima desse limiar indicando preocupação e, de certa forma, um conhecimento empírico acumulado ao longo de uma vida que desde o nascimento vivencia a prática da atividade rural.

Este estudo foi realizado com base nas análises de solo, realizadas pelo Laboratório de Fertilidade da Universidade Federal Rural de Pernambuco - UFRPE, na aplicação de formulários e observações in loco. Dessa forma, foi possível elaborar-se os Biogramas de Sustentabilidade aqui apresentados. Um deles, já exposto acima, tem o papel de sintetizar as informações contidas nas dimensões e atributos constitutivos da idéia de sustentabilidade, utilizando-se a média geral.

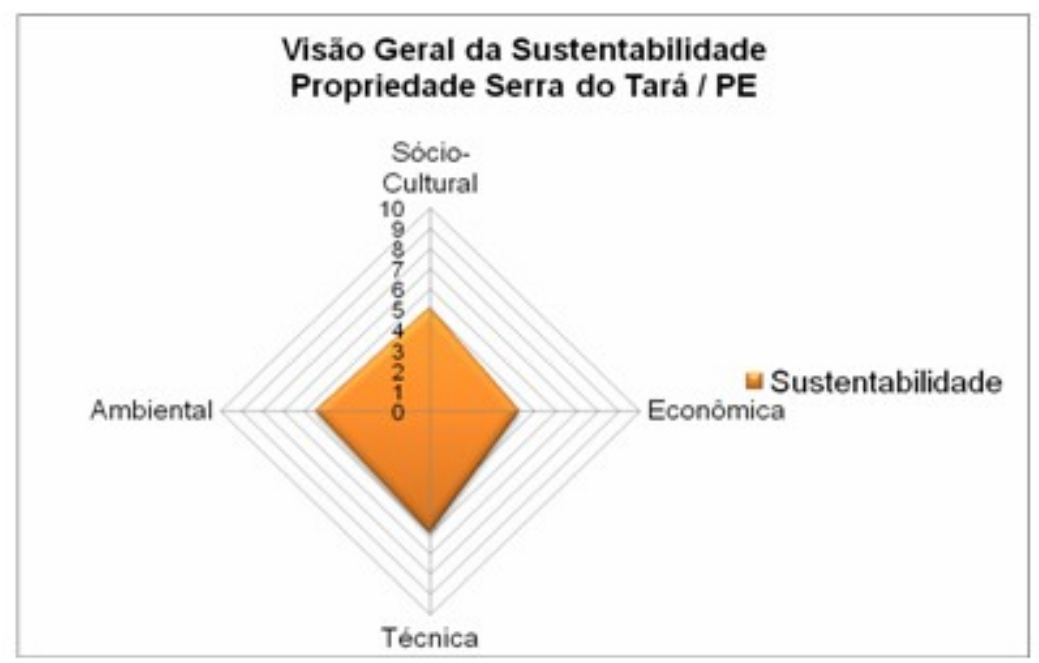

Figura 7.1 - Biograma da Sustentabilidade do Sítio Serra do Tará Fonte: Pesquisa de Campo, abr. 2007

Outro Biograma que se apresenta a seguir tem a função de detalhar e, ao mesmo tempo, integrar os diversos elementos contidos na análise de forma que se tenha, com relativa propriedade, uma visão de como estão integrados, se estão com limiares aceitáveis de sustentabilidade ou se apresentam pontos críticos de sustentabilidade. 


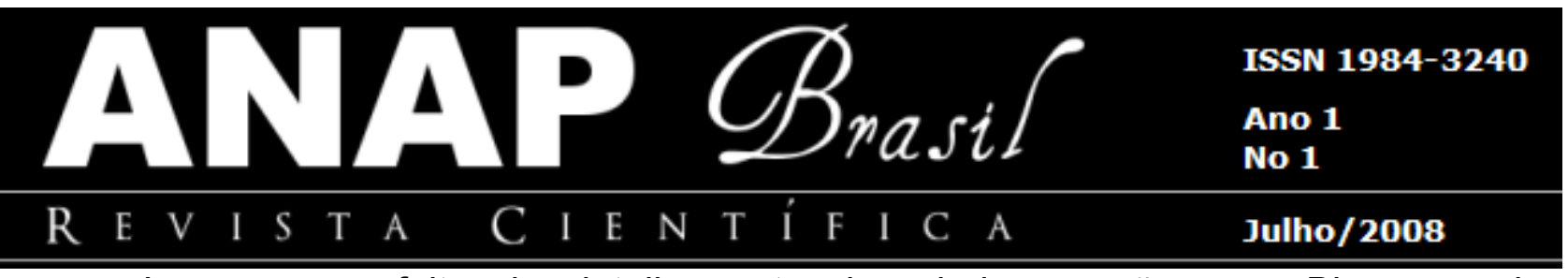

Logo, para efeito de detalhamento dos dados, expõe-se o Biograma das Dimensões de Sustentabilidade da Propriedade Serra do Tará (Figura 7.2), no qual se pode perceber a significativa linha da dimensão sócio-cultural capitaneada pelo atributo integração, aquele que indica se há solidariedade entre os produtores e vizinhos de propriedade.

Nessa mesma dimensão sócio-cultural, porém, fica evidente que as necessidades básicas não estão no limiar da sustentabilidade embora próximo, revelando as precárias condições de vida da família considerando-se, inclusive, o item alimentação. Embora, de certa forma contraditório, a consciência ecológica está presente nas ações e no pensamento do proprietário, apesar de prevalecer a necessidade por recurso alimentar para o gado, ou seja, desmatar a caatinga para plantar palma.

Quando se observa a dimensão econômica em função de seus principais atributos, percebe-se que a renda está no patamar 8, muito boa para os padrões de produção encontrados e frente ao baixo índice de auto-suficiência.

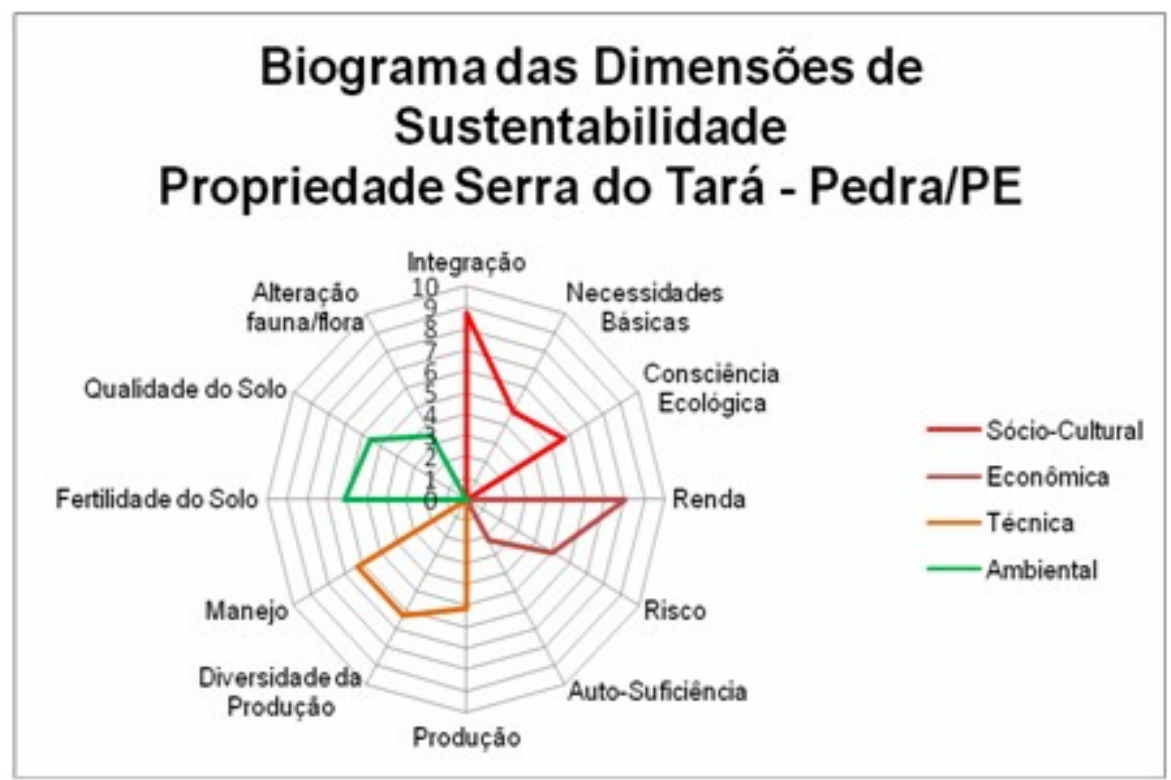

Figura 7.2 - Biograma das Dimensões de Sustentabilidade do Sítio Serra do Tará Fonte: Pesquisa de Campo, abr. 2007

O que favorece essa atividade e essa propriedade, segundo observação feita in loco é o fato de a mesma encontrar-se às margens da rodovia que corta e liga os municípios de Venturosa e Pedra não demandando, em conseqüência, nenhum gasto nem esforço extra para escoar seu produto, principalmente o leite que é apanhado na 


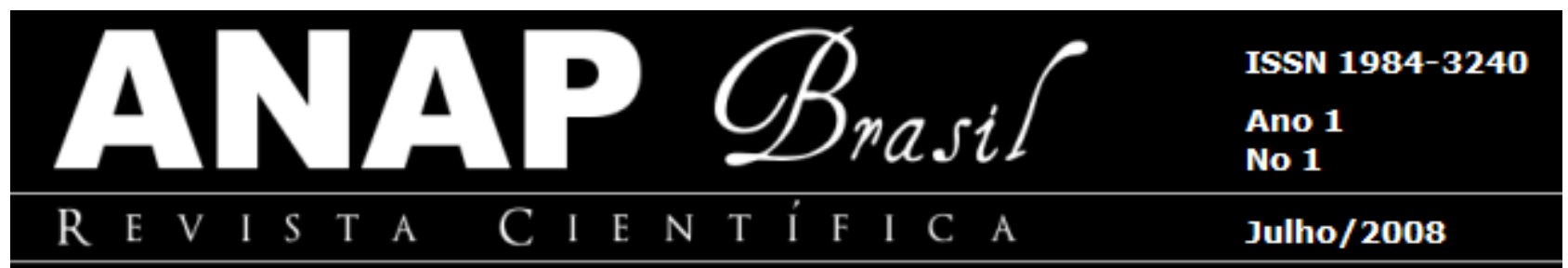

porta. Quanto ao risco, ele está exatamente no limiar da sustentabilidade, sem maiores comentários.

A dimensão técnica, por sua vez, evidencia um manejo relativamente suficiente visto ter atingido um valor acima do nível 6 , acompanhado pelo atributo diversidade da produção tendo o mesmo índice. Salienta-se aqui que há a produção de queijo de coalho e venda de alguns animais quando é o caso, porém a produção está minimamente acima da sustentabilidade, podendo-se admitir que está no nível 5 , ou seja, passível de ser considerado crítico.

Tudo indica que a dimensão que mostra maiores problemas é a ambiental. No caso do atributo fertilidade do solo, as análises proporcionaram um resultado razoavelmente aceitável, uma vez que o resultado médio atingiu o nível 6 . O mesmo não se pode dizer da qualidade do solo, apesar de se encontrar com valor 5,5, acima do limiar médio de sustentabilidade. Mas, apesar de todas as condições adversas de estrutura e disposição física desse solo, trata-se de um resultado aceitável. O problema, ou o ponto crítico reside mesmo no atributo referente à alteração da fauna e flora que atingiu, apenas, 3,5 ficando bem abaixo do que pode se considerar sustentável. Esse resultado, no entanto, se coaduna com outros, em outras dimensões inclusive, como a consciência ecológica, o que interessa mesmo é o momento, a oportunidade de ganhar algum dinheiro mesmo que se tenha que derrubar os resquícios de caatinga, ainda, existentes na propriedade.

\section{CONSIDERAÇÕES FINAIS}

Considera-se, então, apropriado o uso dessas metodologias em estudos que adotem a visão sistêmica na percepção da sustentabilidade, em especial no âmbito da Geografia Agrária. Através dos dados obtidos e trabalhados, os quais resultaram em cartogramas dos níveis categóricos de um lado, na concepção da Geografia Física e, do outro os biogramas de sustentabilidade na perspectiva dos estudos agroecológicos, obteve-se um diagnóstico com potencial para intervenção, notadamente com a participação do produtor, no agroecossistema pecuário que, pode ser incorporado na 


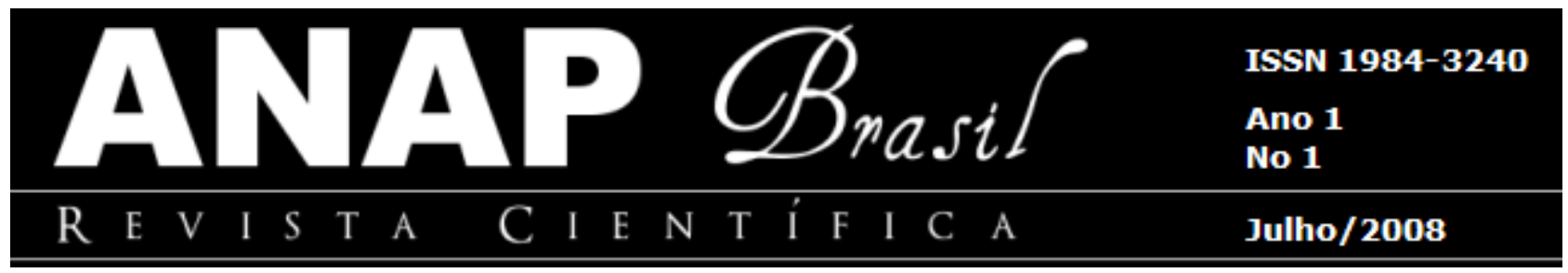

melhoria do sistema produtivo e de bem-estar humano e animal no contexto do desenvolvimento rural.

\section{REFERÊNCIAS}

ASSOCIAÇÃO BRASILEIRA DE NORMAS TÉCNICAS, NBR 6023: informação e documentação: referências: elaboração. Rio de Janeiro, 2002.

Carta de Reconhecimento de Baixa e Média Intensidade de Solos, produzida pela Empresa de Pesquisa Agropecuária - Pernambuco (EMBRAPA, 1999), folha Venturosa SC $24-X-B-V$. Escala: 1: 100000.

CAVALCANTI, Francisco José de A. Recomendações de adubação para o estado de Pernambuco (2ª aproximação). Recife: IPA, 1998.

CORRÊA, Antonio Carlos de; AZAMBUJA, Renata Nunes. Avaliação qualitativa em microescala da estabilidade da paisagem em áreas sujeitas a desertificação no ambiente semiárido do Nordeste do Brasil. Anais do XI Simpósio Brasileiro de Geografia Física Aplicada. USP: São Paulo, 2005.

EMPRESA BRASILEIRA DE PESQUISA AGROPECUÁRIA (EMBRAPA Solos). Levantamento de Baixa e Média Intensidade dos Solos do Estado de Pernambuco. Municípios de Venturosa e Pedra. Escala: 1:100.000: Recife: Embrapa, 2000. Disponível em: http://www.cnps.embrapa.br/zapenet/mapalevantamentoueprecife.htm. Acesso em 20 mar. 2006.

GLIESSMAN, Stephen R. Agroecologia: processos ecológicos em agricultura sustentável. 3 ed. Porto Alegre: Editora da UFRGS, 2005.

INSTITUTO DA POTASSA \& FOSFATO. Manual internacional de fertilidade do solo. 2 ed. Tradução e adaptação de Alfredo Sched Lopes. Piracicaba: POTAFOS, 1998.

MALAVOLTA, Eurípedes. Potássio - absorção, transporte e redistribuição na planta.

Potafos: encarte técnico. Informações Agronômicas, n. 108, dez. 2004.

MENDES, Benedito Vasconcelos. Potencialidades de utilização da algaroba [Prosopis juliflora (SW) DC] no semi-árido brasileiro. 2 ed. Mossoró,RN: ESAM, 1989.

SILVA, Durval Morais da. Plantas tóxicas para ruminantes e eqüídeos no Seridó

Ocidental e Seridó Oriental do Rio Grande do Norte. 2006. 85 f. Dissertação (Mestrado 


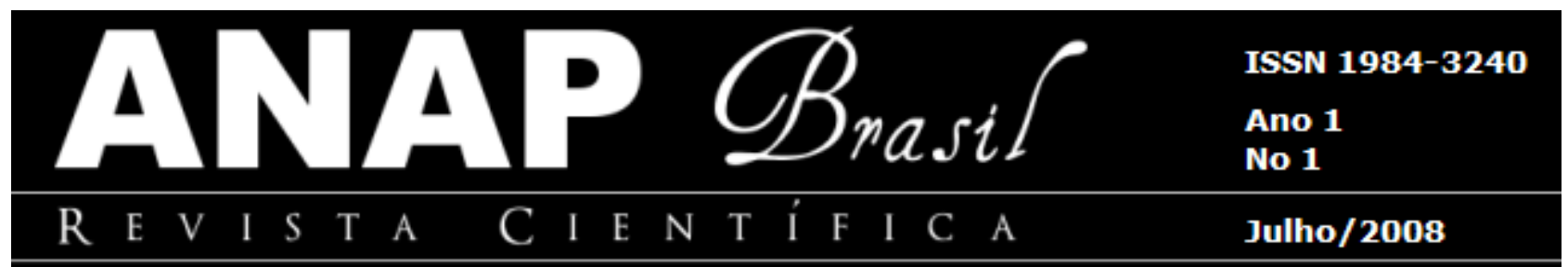

em Medicina Veterinária em Pequenos Ruminantes) - Centro de Saúde e Tecnologia Rural, Universidade Federal de Campina Grande, Paraíba.

TRICART, Jean. Ecodinâmica. Rio de Janeiro: Diretoria Técnica: SUPREN, 1977.

USAID - Agencia para el Desarrollo Internacional de los Estados Unidos. Parte Del Pryecto de Reactivación Agrícola de Honduras (ZAMORANO/USAID). Guía Salud de Suelos: manual para el cuidado de la salud de suelos: para agricultores, promotores y extensionistas. Faculdad de La Universidad de Cornell y La Escuela Agrícola Panamericana (El Zamorano), 2000.

USDA - Departamento de Agricultura de los Estados Unidos de Norteamérica. Guía para la evaluación de la calidad y salud del suelo. Traducción al Español del "Soil quality test kit guide" realizada por Alberto Luters e Juan Carlos Salazar Lea Plaza. Instituto de Suelos CRN-CNIA-INTA: Argentina, 2000.

VASCONCELOS SOBRINHO, J. As regiões naturais do Nordeste, o meio e a civilização. Recife: CONDEPE, 1970 (Reimpressão, 2005).

ZAPE - Zoneamento Agroecológico do Estado de Pernambuco. Governo do Estado de Pernambuco. Fernando Barreto Rodrigues e Silva et al. Recife: Embrapa Solos Unidade de Execução e Pesquisa e Desenvolvimento - UEP Recife; Governo do Estado de Pernambuco (Secretaria de Produção Rural e Reforma Agrária), 2001. CD-ROM. (Embrapa Solos. Documentos; n. 35) Brasileira de Pesquisa Agropecuária - EMBRAPA. CD-ROM. 2001. 